\title{
Assessment Process Using the First Year Computer Graphics Course at Uni- versity of Arkansas at Little Rock
}

\section{Dr. Srikanth B Pidugu, University of Arkansas, Little Rock}

Dr. Pidugu is an associate professor of Mechanical Engineering Technology program at University of Arkansas at Little Rock. He obtained Ph.D. in Mechanical Engineering at Old Dominion University in 2001.

Prof. Mamdouh M. Bakr, University of Arkansas, Little Rock

Dr. Swaminadham Midturi, University of Arkansas, Little Rock

Professor of Mechanical Engineering Technology at the University of Arkansas at Little Rock. he has been a member of ABET Evaluator for the past 15 years. He is a former Alexander von Humboldt Foundation Research Fellow of Germany. He has over 35 years of teaching, research, and industry experience.

\section{Prof. George P Tebbetts, University of Arkansas, Little Rock}

George Tebbetts, P.E., is an Associate Professor and Chair in the Department of Engineering Technology at the University of Arkansas at Little Rock. Tebbetts holds an M.S. Mechanical Engineering from the University of New Haven, CT; and a B.S. in Mechanical Engineering from Texas A \& M University. 


\title{
Assessment Process Using the First Year Computer Graphics Course at University of Arkansas at Little Rock
}

\begin{abstract}
Continuous improvement is an important requirement for Engineering Technology programs that are undergoing the accreditation review process by Engineering Technology Accreditation Commission (ETAC) of ABET. This issue will remain important in the future as ABET emphasizes the importance of a continuous improvement process in their review process as it benefits both instructors and their students. The faculty of the Mechanical Engineering Technology (MET) program at the University of Arkansas at Little Rock (UALR) developed a general assessment method to evaluate the student outcomes of the ABET- Engineering Technology Accreditation criteria (a) through (k) as a part of their accreditation process [1]. Different courses in the MET program are used to evaluate and assess these student outcomes. The indirect student self-assessment scores and the direct student performance scores are correlated to assess the student outcomes. In addition to describing the general assessment method, this paper describes a specific course to explain the assessment process. We selected the first year computer graphics course to satisfy the student outcome (f) of the Associate of Science (AS) degree. The student outcome (f) places significant emphasis on written, oral, and graphical communication. Though the assessment method is general, this paper describes how it is applied to computer graphics course. In this paper, we present the course structure, assessment method and continuous improvement process.
\end{abstract}

\section{Introduction}

The Mechanical Engineering Technology (MET) program at UALR went through an ABET review process recently. The objective of this paper is to discuss the general assessment method developed by the MET faculty at UALR to evaluate student outcomes of the ABETEngineering Technology Accreditation Committee Criterion 3 - Student Outcomes. Though there are number of methods available to evaluate ABET criterion [2-3], this method is general enough to evaluate any select student outcome using an appropriate course from the curriculum. Both direct and indirect assessments are used to evaluate the student outcomes. Though faculty keep graded student work for the assessment purpose, it is not practical to keep the entire set of graded work -- graded quizzes, tests, lab reports etc. through a six year period. However, the question papers and other relevant information such as tests, quizzes and lab reports and student grade sheets are scanned and stored in electronic format. Our assessment method entirely depends primarily on the exam papers and the final student grade sheet. The basic assumption in this model is that the contents of each course are taught in the same sequence whenever it is taught. When we examined this assumption over the six year period, it is found to be accurate enough, that we could apply this model with reasonable confidence to assess the student outcomes. For our recent ABET accreditation review, we implemented this model with considerable success.

The main goal of this paper is to present the methodology used in this model. A unique feature of our model is a comparison of the indirect student self-assessment scores with the direct assessment scores obtained through exams, quizzes, lab reports and special projects, on a scale of 1 through 5 (with 1 being the highest level of achievement). First the paper describes the 
assessment method for the MET degree program and then the presents how the method is applied to the computer graphics course to assess specific student outcome(s). We selected a first year computer graphics course to satisfy criterion (f) of the associate of science (AS) degree. Per to ETAC of ABET, student outcome (f) requires that the program must demonstrate students' ability to apply written, oral, and graphical communication in both technical and non-technical environments; and an ability to identify and use appropriate technical literature.

\section{Structure of Computer Graphics Course}

The first year computer graphics course at UALR is a traditional engineering drawings course and the course incorporates the use of modern tools such as AutoCAD. This course is for three semester credit hours with 30 contact lecture hours and 45 laboratory contact hours in a semester. The catalog description includes studying of the types of engineering drawings used in design, sketching, drafting standards, and using computer-aided design software to create various types of views needed in design and documentation.

By the end of the semester, students are expected to achieve the following specific goals:

1. Develop sketching skills needed to illustrate ideas quickly

2. Understand projection theory

3. Learn to use two-dimensional computer aided design software (AutoCad)

4. Understand standards and conventions associated with engineering drawings

The topics covered in this course include introduction to engineering drawings, free hand sketching in engineering design, engineering geometry, fundamentals of AutoCAD, introduction to 2-D construction using AutoCAD, advanced AutoCAD commands, multiviews, isometric, oblique, and perspective sketching/drawings, auxiliary and section views, dimensioning, working drawings, electronic drawings, threads and fasteners. Direct assessment tools include bi-weekly quizzes, three exams and approximately 25 laboratory exercises. Students have to earn a grade of $\mathrm{C}$ or better to take the next course which is Computer Aided Design.

\section{Development of the General Assessment Model}

The student outcomes are a part of a review cycle, which is conducted every three years (or sooner if needed) by the MET program in consultation with its Industrial Advisory Council (IAC). The program faculty reviews the program educational objectives (PEOs) with the IAC and discusses how the curriculum is enabling the PEOs. The MET Program used Direct Assessment (DA) and Indirect Assessment (IDA) methods to evaluate the student outcomes (SOs) of ETAC of ABET Criterion 3 (a) through (i) for the A.S. degree. The same process is also used to evaluate the student outcomes (SOs) of ETAC of ABET Criterion 3 (a) through (k), and also the Department's MET specific Criteria (l) through (o) for the B.S. program. The specific criteria (l to o) developed by the MET faculty reflect the characteristic essence of the courses offered through the MET curriculum which emphasizes design, materials, manufacturing, and fluid and thermal equipment areas. This focus in the MET curriculum is shown to have met the local industry needs. Our DA and IDA methods assess student (learning) outcomes satisfying the 
MET specific criteria are in coincidence with ETAC Criteria. It's also to be noted however, that there is a considerable overlap between ETAC and MET specific criteria.

Two methods -Direct and Indirect Assessment methods are used to assess the student outcomes of METs. The DA method uses semester exams, quizzes, projects, lab reports, independent study papers, and capstone design projects, and the IDA method uses end of the semester self-assessment by students. As pointed out earlier, we need only the raw scores and the test papers for this model but not the actual graded student work. The following paragraphs describe the DA and IDA methods and show how they are used in assessing the student outcomes to meet the ETAC and MET specific criteria. This is a four step process which includes: (a) a detailed mapping of MET courses with ETAC criteria, shown in table 1, (b) tabulating scores from exams, quizzes, projects, and labs in select courses and converting the scores into a score that can be compared to IDA scores, (c) comparing the DA and IDA scores for each of the student outcomes, and (d) providing a summary of findings, corrective actions, and level of achievement for each of the student outcomes from the selected courses.

Table 1: Mapping of ETME Courses to ETAC Student Outcomes

\begin{tabular}{|c|c|c|c|c|c|c|c|c|c|c|c|}
\hline \multicolumn{12}{|c|}{ Map of Student Outcomes to ETME COURSES } \\
\hline & & & \multicolumn{9}{|c|}{ AS ABET Student Outcomes } \\
\hline \multicolumn{3}{|c|}{ MET COURSES } & $\begin{array}{l}\text { a) An ability } \\
\text { to apply the } \\
\text { knowledge, } \\
\text { techniques, } \\
\text { skills \& } \\
\text { modern tools } \\
\text { of the } \\
\text { discipline to } \\
\text { narrowly } \\
\text { defined } \\
\text { engineering } \\
\text { technology } \\
\text { activities }\end{array}$ & \begin{tabular}{|l|} 
b) An ability to apply \\
a knowledge of \\
mathematics, \\
science, \\
engineering, and \\
technology to \\
engineering \\
technology problems \\
that require linited \\
application of \\
principles but \\
extensive practical \\
knowledge
\end{tabular} & \begin{tabular}{|l|} 
c) An ability \\
to conduct \\
standard \\
tests and \\
measurement \\
s and to \\
conduct, \\
analyze, and \\
interpret \\
experiments \\
\end{tabular} & $\begin{array}{l}\text { d) An ability to } \\
\text { function } \\
\text { effectively as a } \\
\text { member of a } \\
\text { technical team } \\
\end{array}$ & \begin{tabular}{|l} 
e) An ability \\
to identify, \\
analyze, and \\
solve \\
narrowly \\
defined \\
engineering \\
technology \\
problems
\end{tabular} & \begin{tabular}{|l|} 
f) An ability to \\
apply written, \\
oral, and \\
graphical \\
communication in \\
both technical \\
and nontechnical \\
environments; \\
and an ability to \\
identify and use \\
appropriate \\
technical \\
literature
\end{tabular} & $\begin{array}{l}\text { g) An } \\
\text { understandin } \\
\text { g of the need } \\
\text { for and an } \\
\text { ability to } \\
\text { engage in } \\
\text { self-directed } \\
\text { continuing } \\
\text { professional } \\
\text { development }\end{array}$ & $\begin{array}{c}\text { h) An } \\
\text { understanding } \\
\text { of and a } \\
\text { commitment to } \\
\text { address } \\
\text { protessional } \\
\text { and ethical } \\
\text { responsibilties } \\
\text { including a } \\
\text { respect for } \\
\text { diversity }\end{array}$ & $\begin{array}{c}\text { i) A } \\
\text { commitment } \\
\text { to quality, } \\
\text { timeliness } \\
\text { and } \\
\text { continuous } \\
\text { improvement }\end{array}$ \\
\hline \multirow{12}{*}{ 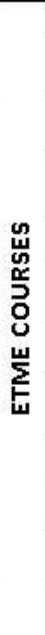 } & ETME 1300 & Computer Graphics & - & & & & & $\mathrm{x}$ & & - & \\
\hline & ECET 1302 & $\begin{array}{l}\text { Intro Exper Tech } \\
\& \text { Computers }\end{array}$ & - & & & & $\bullet$ & & & & \\
\hline & ETME 2302 & $\begin{array}{c}\text { Properties } \\
\text { of Materials }\end{array}$ & $\bullet$ & & $\bullet$ & $\bullet$ & & & & & \\
\hline & ETME 2303 & $\begin{array}{l}\text { Computer Aided } \\
\text { Design }\end{array}$ & $\bullet$ & & & & & & & & $\bullet$ \\
\hline & ETME 2117 & $\begin{array}{l}\text { Manufacturing Proc } \\
\text { Lab }\end{array}$ & & $x$ & $\bullet$ & $x$ & $\bullet$ & & & $x$ & \\
\hline & ETME 2317 & $\begin{array}{l}\text { Manufacturing } \\
\text { Processes }\end{array}$ & - & $\bullet$ & & & & & $\mathrm{x}$ & & $x$ \\
\hline & ETME 2333 & $\begin{array}{l}\text { Advanced } \\
\text { CAD }\end{array}$ & $\bullet$ & & & & & $\bullet$ & & & \\
\hline & ETME 2320 & $\begin{array}{l}\text { Fluid Mechanics } \\
\text { \& Power }\end{array}$ & $x$ & - & $\mathrm{x}$ & - & & - & - & & \\
\hline & ETME 3317 & $\begin{array}{c}\text { Statics \& } \\
\text { Dynamics }\end{array}$ & $\bullet$ & $\bullet$ & & & $\mathrm{x}$ & & & $\bullet$ & \\
\hline & ECET 1404 & Circuit Analysis I & - & - & - & & - & & & & - \\
\hline & ECET 3308 & $\begin{array}{l}\text { Robotics \& } \\
\text { PLCs }\end{array}$ & $\bullet$ & & $\bullet$ & $\bullet$ & & & & & \\
\hline & IFSC 2200 & $\begin{array}{l}\text { Ethics in the } \\
\text { Profession }\end{array}$ & - & $\bullet$ & $\bullet$ & & $\bullet$ & & & $x$ & \\
\hline
\end{tabular}

The table 2 presents a partial list of student outcomes of ETAC of ABET Criterion 3 (a-i) to show the selected group of courses that best meet the SOs in ETAC Criteria. It may be noted that some columns and rows of most tables presented in paper are removed to fit in the available space. The assessment process and evaluation methods described above are adopted to evaluate 
the SOs in the course on ETME 1300. We chose ETME 1300 (Computer Graphics) to meet the ETAC Criterion 3 (f). This course has significant emphasis on communication, and closely meets the criterion 3 (f). Similar matching of MET courses and the SOs for AS degree is indicated in table 2 .

Table 2: A Partial list of Student Outcomes for the AS Degree: ETAC Criteria, MET Courses, Frequency, and Attainment

\begin{tabular}{|c|c|c|c|}
\hline $\begin{array}{c}\text { ETAC/MET } \\
\text { Student } \\
\text { Outcomes }\end{array}$ & $\begin{array}{c}\text { ETME } \\
\text { Course(s) }\end{array}$ & $\begin{array}{c}\text { Frequency } \\
\text { of Assessment }\end{array}$ & $\begin{array}{c}\text { Achievement } \\
\text { Expected/ Attained } \\
\text { (Based on DA } \\
\text { scores) }\end{array}$ \\
\hline $\mathrm{a}$ & $\begin{array}{c}\text { Fluid Power \& } \\
\text { Mechanics } \\
2320\end{array}$ & Biennial & Average/Good \\
\hline b & $\begin{array}{l}\text { Manufacturing } \\
\text { Processes } \\
\text { Laboratory } \\
2117\end{array}$ & Once a Year & Average/Good \\
\hline e & $\begin{array}{c}\text { Statics \& } \\
\text { Dynamics } \\
3317 \\
\end{array}$ & Biennial & Average/Good \\
\hline $\mathbf{f}$ & $\begin{array}{c}\text { Computer } \\
\text { Graphics } \\
1300\end{array}$ & Once a Year & Average/Good \\
\hline h & $\begin{array}{l}\text { Manufacturing } \\
\text { Processes } \\
\text { Laboratory } \\
2117 \\
\text { Ethics in the } \\
\text { Profession } \\
\text { IFSC } 2200\end{array}$ & Once a Year & 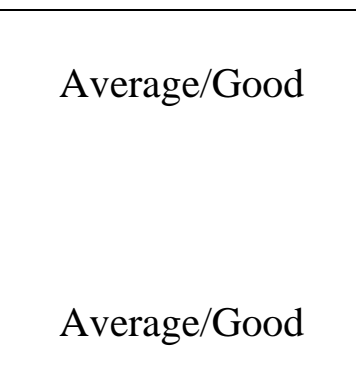 \\
\hline $\mathrm{i}$ & $\begin{array}{c}\text { Manufacturing } \\
\text { Processes } \\
2317 \\
\end{array}$ & Once a Year & Average/Good \\
\hline
\end{tabular}

\section{$\underline{\text { Explanation of Direct Assessment and Indirect Assessment Method Scores }}$}

Table 2 in the previous section is a summary table. It indicates Student Outcomes and the level of achievement for each of the SOs. In the following paragraphs, we'll explain how the direct assessment scores are obtained, converted to scale 1-5, and compared with the indirect assessment scores. 
Year-wise student performance in exams, quizzes, labs, projects was evaluated, from 2008 - 2012, for majority of MET courses. Scores from selected exams, quizzes, etc. form the basis for the direct assessment scores. The first step in the assessment process is the mapping of course learning objects and student outcomes with specific tests and labs (Table 3). For example, under direct assessment, we used quiz 3 , quiz 4 , exam 1, exam 2, and all the labs to evaluate student outcome f. Under indirect assessment, end of the semester student evaluation items 11 through 15 are used. The students evaluate course, instructor as well as themselves. For example, item 14 states "I am capable of creating multiviews, section views, and auxiliary views". The student rates his/her learning of this specific course learning objective. The student assigns one if he/she strongly agrees with the statement and 5 if he/she strongly disagrees. It may be noted that the developed method can be used not only for evaluating student outcome $f$ but also the course itself.

Table 3: ETME 1300: Computer Graphics - Assessment Method (Mapping)

\begin{tabular}{|c|c|c|c|c|c|c|c|c|c|c|c|c|}
\hline \multirow{2}{*}{$\begin{array}{l}\text { Learning } \\
\text { Objectives/ } \\
\text { Student } \\
\text { Outcomes }\end{array}$} & \multirow{2}{*}{$\begin{array}{l}P \\
\text { ri } \\
\mathrm{m} \\
\mathrm{a} \\
\mathrm{r} \\
\mathrm{y}\end{array}$} & \multicolumn{9}{|c|}{ Direct Assessment } & \multirow{2}{*}{$\begin{array}{c}\text { Indirect } \\
\text { Assessment/ } \\
\text { Survey } \\
\text { Question }\end{array}$} & \multirow[b]{2}{*}{ Remarks } \\
\hline & & $\begin{array}{l}Q \\
1\end{array}$ & $\begin{array}{l}Q \\
2\end{array}$ & $\begin{array}{l}Q \\
3\end{array}$ & $\begin{array}{l}Q \\
4\end{array}$ & $\begin{array}{l}Q \\
7\end{array}$ & EX1 & EX2 & EX3 & Labs & & \\
\hline $\begin{array}{l}\text { General } \\
\text { Prerequisites, } \\
\text { importance of } \\
\text { course to degree } \\
\text { program etc. }\end{array}$ & & & & & & & & & & & $1-5$ & $\begin{array}{l}\text { No pre- } \\
\text { requisites for } \\
\text { this course }\end{array}$ \\
\hline $\begin{array}{l}\text { Course } \\
\text { 1. Develop } \\
\text { sketching skills } \\
\text { needed to } \\
\text { illustrate ideas } \\
\text { quickly ( deleted } \\
\text { course objectives } \\
3,4 \text { due to space } \\
\text { restrictions }\end{array}$ & $\bullet$ & $\bullet$ & $\bullet$ & $\bullet$ & & & $\bullet$ & & & $\bullet$ & 11,13 & \\
\hline $\begin{array}{l}\text { 2. Understand } \\
\text { project theory }\end{array}$ & $\bullet$ & $\bullet$ & $\bullet$ & $\bullet$ & & & $\bullet$ & & & $\bullet$ & 14 & \\
\hline $\begin{array}{l}\text { ABET-ETAC (f) } \\
\text { (f) An ability to } \\
\text { apply written, } \\
\text { oral, and graphical } \\
\text { communication in } \\
\text { both technical and } \\
\text { non-technical } \\
\text { environments; } \\
\text { and an ability to } \\
\text { identify .... }\end{array}$ & $\mathbf{x}$ & & & $\bullet$ & & $\bullet$ & $\bullet$ & $\bullet$ & & $\bullet$ & $11-15$ & $\begin{array}{l}X- \\
\text { Assessed } \\
\text { ABET- } \\
\text { ETAC } \\
\text { criterion } \\
\text { (f) }\end{array}$ \\
\hline
\end{tabular}


Table 4 shows the raw class average scores obtained in the selected quizzes, exams, and lab exercises. Maximum possible score in each quiz is 15 but the table shows the converted score which is 100. A similar procedure is adopted for lab exercises. Mid-term and finals examinations are usually worth 100 points. Even though quizzes and labs are not always out of 100, the DA scores are based on maximum score of 100 . Comments under the remarks column also gives some idea on how students perform during each semester for a specific course learning objective. For example, low scores in quiz 1, quiz 2, and quiz 3 resulted in poor performance in fall 2008 for course learning objective 1:-"Develop sketching skills needed to illustrate ideas quickly". Similarly it is observed that in Fall 2010, the students performed very well and most of them continued in the program and are close to graduation at this time.

Table 4: ETME 1300: Computer Graphics - Direct Assessment Scores

\begin{tabular}{|c|c|c|c|c|c|c|c|c|c|c|c|c|}
\hline \multirow{2}{*}{ Term } & \multicolumn{11}{|c|}{$\begin{array}{l}\text { Direct Assessment } \\
\text { Class Average Score - Maximum Score } 100\end{array}$} & \multirow{2}{*}{ Remarks } \\
\hline & Q1 & Q2 & Q3 & Q4 & Q5 & Q6 & Q7 & EX1 & EX2 & EX3 & Labs & \\
\hline $\begin{array}{l}\text { Fall } \\
07\end{array}$ & 69.2 & 60.5 & 63.6 & 65.6 & 56.9 & 82.1 & 69.7 & 81.9 & 78.3 & 70.6 & 83.4 & \\
\hline $\begin{array}{c}\text { Fall } \\
08\end{array}$ & 45.2 & 54.3 & 56.7 & 51.4 & 80 & 74.3 & 65.2 & 76.7 & 83.0 & 79.8 & 76.2 & $\begin{array}{l}\text { Unusually low } \\
\text { score in quiz } \\
1 \text {, quiz 2, quiz } \\
3 \text { resulted in } \\
\text { poor } \\
\text { performance } \\
\text { in fall } 2008 \\
\text { for course } \\
\text { learning } \\
\text { objective 1: } \\
\text { Develop } \\
\text { sketching } \\
\text { skills needed } \\
\text { to illustrate } \\
\text { ideas quickly }\end{array}$ \\
\hline $\begin{array}{l}\text { Fall } \\
09\end{array}$ & 60.0 & 60.4 & 66.7 & 64.7 & 56.1 & 77.7 & 61.2 & 77.8 & 81.9 & 79.3 & 87.2 & \\
\hline $\begin{array}{l}\text { Fall } \\
10\end{array}$ & 83.3 & 81.7 & 78.5 & 80.0 & 51.7 & 90 & 80.4 & 83.4 & 80.9 & 79.1 & 90.0 & $\begin{array}{l}\text { Good overall } \\
\text { performance } \\
\text { in Fall } 2010 . \\
\text { Many of the } \\
\text { students are } \\
\text { continuing in } \\
\text { either MET or } \\
\text { ECET program }\end{array}$ \\
\hline $\begin{array}{l}\text { Fall } \\
11\end{array}$ & 66.3 & 60.8 & 82.5 & 73.8 & 50.0 & 62.9 & 70.8 & 83.7 & 79.9 & 70.0 & 82.5 & \\
\hline
\end{tabular}


In the next step, comparing direct scores and indirect scores, first direct scores are converted to a scale from 1 through 5, with 1 representing the highest level of achievement (excellent), and 5 the lowest. This conversion is based on the mapping shown in the table 3. For example, direct assessment of score 2.43 for student outcome "f" in fall 2009 is obtained in the following manner. First the average of quiz 3 (66.7), quiz4 (64.7), exam 1(77.8), exam 2 (81.9), and all the laboratory (87.2) raw scores (Refer table 3 and table 4) is obtained which is 75.7. Again, mapping in table 3 guides what quizzes/exams/labs need to be selected for calculating the average score. Table 4 gives average raw scores for the selected quizzes/exams/labs. Finally, the average score is divided by 10 and then subtracted from 10 to get final scaled direct assessment score of 2.43. The indirect score of 1.25 for student outcome $\mathrm{f}$ in fall 2009 is obtained by taking the average of student evaluation scores for questions 11-15 (table 3). It may be noted indirect assessment scores for each question $(11-15)$ are not shown.

Table 5: ETME 1300: Computer Graphics - Scaled Direct Assessment \& Indirect Assessment Scores

\begin{tabular}{|c|c|c|c|c|c|c|c|}
\hline \multirow{3}{*}{$\begin{array}{c}\text { Learning } \\
\text { Objectives/Student } \\
\text { Outcomes }\end{array}$} & \multicolumn{6}{|c|}{ Assessment Scores } & \multirow{3}{*}{ Remarks } \\
\hline & \multicolumn{2}{|c|}{ Fall 09} & \multicolumn{2}{|c|}{ Fall 10} & \multicolumn{2}{|c|}{ Fall 11} & \\
\hline & Direct & Indirect & Direct & Indirect & Direct & Indirect & \\
\hline General & N/A & $1.56^{*}$ & $\mathrm{~N} / \mathrm{A}$ & 1.84 & $\mathrm{~N} / \mathrm{A}$ & 1.46 & $\begin{array}{l}\text { N/A Not } \\
\text { Available }\end{array}$ \\
\hline $\begin{array}{l}\text { Course (student self-assessment } \\
\text { related to specific topics) } \\
\text { 1. Develop sketching skills } \\
\text { needed to illustrate ... }\end{array}$ & 2.96 & 1.30 & 1.66 & 1.72 & 2.48 & 1.20 & \\
\hline $\begin{array}{l}\text { 3. Learn to use two-dimensional } \\
\text { computer aided ... }\end{array}$ & 2.37 & 1.20 & 1.6 & 1.58 & 2.85 & 1.20 & \\
\hline $\begin{array}{l}\text { ABET-ETAC (f) } \\
\text { (f) An ability to apply written, } \\
\text { oral, and graphical } \\
\text { communication ... }\end{array}$ & 2.43 & 1.25 & 1.80 & 1.57 & 2.18 & 1.17 & $\begin{array}{l}\text { Assessed } \\
\text { ABET-ETAC } \\
\text { criterion (f) }\end{array}$ \\
\hline \multicolumn{8}{|c|}{$\begin{array}{l}\text { Assessment Scores/ Performance: Excellent } \rightarrow 0-1, \quad \text { Good } \rightarrow 1-2, \quad \text { Average } \rightarrow 2-3 \text {, } \\
\text { Below Average } \rightarrow 3-4 \quad \text { Failing } \rightarrow \text { - }-5\end{array}$} \\
\hline
\end{tabular}

The final and important phase of assessing Student Outcomes is to identify the general and specific concerns and issues in student learning (outcomes), and to suggest appropriate recommendations to correct the concerns, where needed. These corrective actions and plans are indicated for each criterion and for the selected course as shown in table 6 for student outcome $\mathrm{f}$. 
Table 6. Student Outcomes: ABET- ETAC Criterion (f) - AS Degree "An ability to apply written, oral, and graphical communication in both technical and non-technical environments; and an ability to identify and use appropriate technical literature"

\begin{tabular}{|c|c|c|c|c|c|c|c|}
\hline \multirow{2}{*}{ Courses } & \multirow{2}{*}{$\begin{array}{l}\text { Method of } \\
\text { Assessment }\end{array}$} & \multirow{2}{*}{ Frequency } & \multicolumn{4}{|c|}{ Assessment scores* } & \multirow{2}{*}{$\begin{array}{l}\text { Findings/Corrective } \\
\text { Action/Continuous } \\
\text { Improvement }\end{array}$} \\
\hline & & & $\begin{array}{l}\text { Fall } \\
2008\end{array}$ & $\begin{array}{l}\text { Fall } \\
2009\end{array}$ & $\begin{array}{l}\text { Fall } \\
2010\end{array}$ & $\begin{array}{l}\text { Fall } \\
2011\end{array}$ & \\
\hline \multirow[t]{2}{*}{$\begin{array}{l}\text { ETME } \\
\text { 1300: } \\
\text { Comput } \\
\text { er } \\
\text { Graphic } \\
\text { s }\end{array}$} & $\begin{array}{l}\frac{\text { Quiz 3, Quiz 7, }}{\text { exam 1, exam 2, }} \\
\frac{\text { exam 3 \& labs }}{\text { The above }} \\
\text { quizzes, exams } \\
\text { and labs used as } \\
\text { a part of direct } \\
\text { assessment } \\
\text { specifically tests } \\
\text { the students' } \\
\text { (i) written, oral, } \\
\text { and graphical } \\
\text { communication } \\
\text { skills } \\
\text { (ii) } \\
\text { understanding } \\
\text { of standards and } \\
\text { conventions } \\
\text { used in } \\
\text { engineering } \\
\text { drawings } \\
\text { (iii) research } \\
\text { ability to get } \\
\text { information } \\
\text { from published } \\
\text { and online } \\
\text { literature }\end{array}$ & $\begin{array}{l}\text { Once a year } \\
\text { (course } \\
\text { taught } \\
\text { during both } \\
\text { spring and } \\
\text { fall } \\
\text { semester) }\end{array}$ & 2.71 & 2.43 & 1.80 & 2.18 & $\begin{array}{l}\text { Overall, students } \\
\text { performed at high level on } \\
\text { consistent basis and direct } \\
\text { assessment clearly } \\
\text { indicated that the student } \\
\text { performance is average } \\
\text { which is the minimum } \\
\text { desired expected level of } \\
\text { achievement. Based on } \\
\text { direct assessment results, } \\
\text { students met performance } \\
\text { criterion to apply written, } \\
\text { oral, and graphical } \\
\text { communication in both } \\
\text { technical and non- } \\
\text { technical environments; } \\
\text { and also to identify and } \\
\text { use appropriate technical } \\
\text { literature. } \\
\text { As a part of continuous } \\
\text { improvement plan, } \\
\text { following actions have } \\
\text { been taken: } \\
\text { (i) Provide more one-to- } \\
\text { one help on CAD } \\
\text { based labs. } \\
\text { (ii) Provide more help on } \\
\text { topics such as section } \\
\text { and auxiliary views. } \\
\text { Though ABET/ETAC } \\
\text { criterion is satisfied, } \\
\text { detailed explanation for } \\
\text { overall inconsistent } \\
\text { performance is provided in } \\
\text { the course binder. }\end{array}$ \\
\hline & $\begin{array}{l}\text { Indirect } \\
\text { Assessment-End } \\
\text { of Semester } \\
\text { student Course } \\
\text { Evaluations }\end{array}$ & Once a Year & N/A & 1.25 & 1.57 & 1.17 & $\begin{array}{l}\text { The student ratings are } \\
\text { consistently high and fall } \\
\text { between } 1-2 \text { (good). }\end{array}$ \\
\hline
\end{tabular}




\section{Conclusion}

A general assessment method developed to evaluate ETAC of ABET student outcomes is applied to measure Student Outcomes in ETME 1300, Computer Graphics based on raw scores. Both direct and indirect assessment tools are used in this model. Direct assessment scores are based on quizzes / tests / labs reports and indirect assessment scores are based on end of the semester student self-evaluations. The salient feature of this method is that it is possible to assess the student outcomes without having individual graded student work. This method not only assesses the ETAC of ABET student outcomes, but also the student learning outcomes in the individual courses.

\section{References}

1. Criteria for Accrediting Engineering Technology Programs, 2011 - 2012. Retrieved from ABET website (http://www.abet.org/uploadedFiles/Accreditation/Accreditation_Process/Accreditation_Documents/Curren t/abet-tac-criteria-2011-2012.pdf)

2. Agoki, G and Ng, B-C., 2012, Using First Year Engineering Graphics Course for Student Outcomes and Assessment. 66 ${ }^{\text {th }}$ Midyear Meeting Proceedings January 22-24, 2012 Galveston, TX

3. Kirstukas, S. J., \& Al-Masoud, N., 2012, Assessment and Evaluation of ABET Outcomes c and k in Engineering Courses that Utilize Solid Modeling Packages. $119^{\text {th }}$ ASEE Annual Conference and Exposition, June 10-13, 2012, San Antonio, TX 